\title{
Ewolucja planowania finansowego w Polsce w latach 1945-1990
}

\section{An evolution of a financial planning in Poland in the years 1945-1990}

\begin{abstract}
Streszczenie. Zalety wieloletniego planowania finansowego dostrzegane były w Polsce już od lat 60. XX w. Mimo że pierwsza próba wieloletniego planowania finansowego, odnosząca się do budżetów lokalnych, miała miejsce dopiero w latach 1961-1965, to już wówczas charakterystyczne było to, że prognozowane kwoty dochodów oraz limity wydatków były nierealne i nieskoordynowane z budżetem państwa. Ponadto wraz z rozwojem myśli dotyczącej wieloletniego planowania finansowego coraz wyraźniej zarysowywała się potrzeba oparcia budżetów terenowych o własne dochody. Należy zaznaczyć, że już w tym okresie pojawiły się także próby odpowiedzi na pierwsze fundamentalne pytania dotyczące wyboru koncepcji wieloletniego planowania finansowego. W tym zakresie na szczególną uwagę zasługuje dyskusja pomiędzy zwolennikami centralistycznego („odgórnego”) sposobu wieloletniego planowania finansowego oraz lokalnego („oddolnego”) wieloletniego planowania finansowego. Pomimo ówczesnej sytuacji politycznej dostrzeżono, że koncepcja wieloletniego planowania finansowego, przygotowywanego „od dołu”, w budżetach terenowych jest bardziej
\end{abstract}


efektywna niż metoda rządowego wieloletniego planowania finansowego realizowanego z wyłączeniem tzw. czynnika obywatelskiego.

Słowa kluczowe: planowanie; planowanie rzeczowe; planowanie finansowe; wieloletnie planowanie finansowe.

\begin{abstract}
Advantages of a multiannual financial planning have been noticed in Poland since the 1960's. First attempts to provide a long-term financial planning took place in Poland in 1961-1965 (at that time this planning referred to local budgets financial planning). However, in the above-mentioned period forecasted amounts of income and spending limits were considered as unrealistic and they were not coordinated with the state budget. In addition, the need to ground local budgets on their own income was more and more clearly evident as ideas regarding the multiannual financial planning have been developed. It should be noted that it was already in 1961-1965 when attempts were made to answer first fundamental questions regarding the choice of the concept of the multiannual planning. Hence, discussion between supporters of the centralized "top-down" and persons who supported the local "bottom-up" multiannual financial planning deserve special attention in this article. Despite a political situation at that time it was noticed that the concept of local budgets' multiannual financial planning (prepared according to the "bottom-up" model) is more effective than the government's multiannual financial planning (which is implemented without an involvement of a so-called civic factor).
\end{abstract}

Keywords: planning; material planning; financial planning; multiannual financial planning.

\title{
1. Wstęp
}

Podstawowym celem badawczym niniejszego opracowania jest zaprezentowanie pierwszych prób zastosowania w Polsce po 1945 r. koncepcji wieloletniego planowania finansowego. Ponadto zadanie badawcze zostało sprowadzone do udzielenia odpowiedzi na pytanie, czy doświadczenia związane z wykorzystaniem wieloletniego planowania finansowego odnosiły się w większym zakresie do budżetów terenowych (lokalnych), czy też dotyczyły głównie budżetu centralnego. Dodatkowo celem artykułu jest udzielenie odpowiedzi na pytanie, jaką rolę w racjonalizacji procesów 
związanych z gromadzeniem i wydatkowaniem środków publicznych odegrały formy wieloletniego planowania finansowego zapoczątkowane w okresie Polskiej Rzeczpospolitej Ludowej.

Geneza planowania budżetowego, a następnie ewolucja planowania wieloletniego bierze swoje początki w działaniach podejmowanych już po II wojnie światowej, kiedy wydłużenie horyzontu czasowego planowania finansowego było przedmiotem badań zarówno w Polsce, objętej wówczas strefą wpływów Związku Radzieckiego, jak i w krajach o ustroju demokratycznym i gospodarce rynkowej.

Pomimo spolaryzowanych systemów politycznych i gospodarczych zalety planowania wieloletniego były na tyle zachęcające, że prowadzone badania miały charakter ponadustrojowy. Trudno bowiem było kwestionować celowość wydłużenia horyzontu planowania budżetowego poza tradycyjny rok, podczas gdy w socjalistycznej polityce centralnie planowanej podejmowane były decyzje, które miały długofalowe konsekwencje wybiegające poza tradycyjne dwanaście miesięcy. Można jedynie podkreślić, że problem z koncepcją planowania wieloletniego, jaki wówczas dostrzeżono po obu stronach żelaznej kurtyny, dotyczył praktycznych możliwości zastosowania planowania wieloletniego.

\section{System planowania rzeczowego \\ a system planowania finansowego}

W okresie socjalistycznym istniały równolegle obok siebie dwa systemy planowania: system planowania rzeczowego i system planowania finansowego. Powszechnie uważano, że planowanie rzeczowe i finansowe stanowiło nierozerwalną całość oraz że konieczna jest jedność planowania rzeczowego i finansowego. W tym znaczeniu podnoszono, że planowanie zadań finansowych jest metodą koordynacji zadań rzeczowych ${ }^{1}$.

Jedność planowania rzeczowego i finansowego uzasadniano także związkiem między procesami rzeczowymi i finansowymi, których nie

1 S. Bolland, Ekonomiczne i ustrojowe aspekty reformy prawa budżetowego, „Ruch Prawniczy i Ekonomiczny”, 1963, nr 3, s. 80. 
można planować w oderwaniu od siebie ${ }^{2}$. Twierdzono przy tym, że zadania rzeczowe i finansowe są wynikiem wzajemnego stosunku procesów rzeczowych i finansowych jako dwóch względnie samodzielnych sfer reprodukcji społecznej ${ }^{3}$ oraz że zadania finansowe były zawsze bądź środkiem, bądź wynikiem realizacji zadań rzeczowych ${ }^{4}$.

Niektórzy autorzy, powołując się na znaną tezę K. Marksa, że produkcja, podział i spożycie są członkami jednej organicznej całości, podkreślali, że również planowanie musi stanowić organiczną całość 5 . Uzasadniano, że jeżeli społeczeństwo socjalistyczne chce gospodarować w pełni efektywnie, musi opierać swą działalność gospodarczą na zasadach rachunku ekonomicznego, to znaczy musi dążyć do osiągnięcia maksymalnych efektów przy danych nakładach albo do pożądanego efektu przy najniższych nakładach ${ }^{6}$.

W literaturze socjalistycznej przyjmowano przeważnie prymat planu społeczno-gospodarczego w stosunku do budżetu państwa. W tym znaczeniu budżet spełniał rolę służebną w stosunku do planu społecznogospodarczego, który stanowił podstawę dla budżetu państwa, który z kolei aktywnie na niego oddziaływał, decydując o realności wykonania planu od strony finansowej ${ }^{7}$.

Pomimo że polskie prawo budżetowe tego okresu nie zawierało co do zasady przepisu, z którego bezpośrednio wynikałaby nadrzędność planu społeczno-gospodarczego w stosunku do budżetu, to jednak w wydawanych corocznie przepisach szczegółowych dotyczących sporządzania pro-

2 Z. Federowicz, Zagadnienie reformy polskiego systemu podatkowego, „Ruch Prawniczy i Ekonomiczny" 1963, nr 3, s. 7.

3 J. Branik, K otazce souladu hmotnych a financnych zdrojom, „Finance a Uver” 1963, nr 4, s. 300-302, cyt. za: J. Kaleta, Gospodarka budżetowa, Warszawa 1985, s. 243.

4 N.S. Margolin, Płanirowanije finansow, Moskwa 1960, cyt. za: J. Kaleta, Gospodarka..., s. 244.

5 M. Weralski, Zwiq̨zki budżetu PRL z narodowym planem gospodarczym i innymi planami finansowymi [w:] W. Brzeziński, J. Kaleta, L. Martan, A. Wolter, M. Weralski (red.), Problemy prawne planowania gospodarczego, Warszawa 1964, s. 108.

6 O. Lange, Optymalne decyzje. Zasady gospodarowania, Warszawa 1964, s. 13 i s. 15.

7 L. Kurowski, Planowanie budżetowe $w$ ramach socjalistycznego planowania gospodarczego, „Państwo i Prawo” 1961, nr 8-9, s. 273. 
jektów planów społeczno-gospodarczych i budżetów ${ }^{8}$ podkreślano, że projekty budżetów powinny być opracowywane na podstawie projektów planu społeczno-gospodarczego ${ }^{9}$. Przesądzony został w ten sposób proces uchwalania przez Sejm budżetu państwa, zaś zbiorczy plan finansowy, początkowo pod nazwą programu finansowego, a następnie bilansu finansowego, sprowadzony został do roli planu analitycznego.

Wraz z docenieniem ekonomicznej części budżetu i planu społeczno-gospodarczego jako czynnika, który w głównej mierze decyduje o randze prawnej tych dokumentów, pierwszeństwo planu społecznogospodarczego zostało zakwestionowane. Podkreślano przy tym, że zaniżanie aktywnej roli planów finansowych powodowało niedostateczne planowanie wariantowe, umożliwiające równoległe planowanie zadań rzeczowych oraz nakładów i efektów finansowych tych zadań w kilku wariantach, dzięki czemu możliwy byłby wybór najefektywniejszego z nich. Stąd traktowanie planów rzeczowych jako pierwotnych i ważniejszych od planów finansowych było główną przyczyną ich statycznego charakteru. Co więcej, planowanie konkretnych zadań rzeczowych w oderwaniu od mechanizmów i instrumentów finansowych stymulujących postęp nie pozwalało na dynamicznie ujmowanie planów gospodarczych ${ }^{10}$.

Zwiększenie znaczenia rachunku ekonomicznego jako podstawowego kryterium planowania gospodarczego oraz stopniowej decentralizacji planowania i zarządzania gospodarką narodową spowodowało, że zasada prymatu planów rzeczowych zdezaktualizowała się ${ }^{11}$. Stopniowo coraz wyraźniej zarysowywał się postulat połączenia aparatu planowania rzeczowego i finansowego. Uzasadnieniem tego poglądu było przekonanie, że sporządzanie projektów budżetów i projektów planów społeczno-gospodarczych przez jeden organ i według jednolitych zasad znacznie

8 Uchwała Rady Ministrów z dnia 17 września 1950 r. w sprawię wstępnych wytycznych do zasad budżetu państwa na 1951 r., Mon. Pol. Nr A-55, poz. 631.

9 Zob. art. 33 ust. 1 ustawy z dnia 3 grudnia 1984 r. Prawo budżetowe, Dz.U. Nr 56, poz. 283 ze zm., dalej: Prawo budżetowe z 1984 r., który stanowił, że Minister Finansów opracowuje projekt budżetu państwa, uwzględniając zadania określone w narodowym planie społeczno-gospodarczym.

10 J. Kaleta, Gospodarka..., s. 247.

11 Tamże, s. 248. 
uprościłoby tryb planowania budżetowego i gospodarczego i niewątpliwie przyczyniłoby się do podniesienia jego efektywności ${ }^{12}$.

Sukcesywnie też zauważano, że budżet państwa nie jest planem całego systemu finansowego, a równowaga budżetu i zamknięty nadwyżką budżet państwa może nie zapewnić równowagi całego systemu finansowego, jeśli np. nadwyżka ta nie umożliwi pokrycia deficytu planu kredytowego ${ }^{13}$. Coraz częściej pojawiały się opinie, że budżet był planem fasadowym, który był prezentowany przed Sejmem i społeczeństwem, i który niezależnie od ogólnej sytuacji finansowej - wykazywał zawsze dobre wyniki ${ }^{14}$.

Dlatego też postulowano, aby Sejm uchwalał w formie uchwały zbiorczy plan państwa równocześnie z narodowym planem gospodarczym. Dopiero wówczas, zdaniem autorów, w oparciu o założenia zbiorczego planu finansowego Sejm miałby uchwalać budżet państwa jako plan dyrektywny dla poszczególnych resortów i rad narodowych ${ }^{15}$.

Podstawowym okresem planowania budżetowego w tym czasie był rok budżetowy, który pokrywał się z rokiem kalendarzowym. W literaturze pojawiały się jednak wnioski ograniczenia planowania budżetowego na okresy krótsze niż rok. Powodem takiego działania było przekonanie, że okresowe nasilanie wydatków budżetowych nie musiało iść w parze ze wzmożonymi wpływami dochodów budżetowych ${ }^{16}$. Konieczność krótkotrwałego planowania budżetowego uzasadniano także potrzebą skoordynowania budżetu z planami finansowymi przedsiębiorstw, planami kredytowymi, planami kasowymi, bilansami dochodów i wydatków ludności, które były ustalane na okresy krótsze niż rok (z reguły kwartalne ${ }^{17}$.

12 Z. Pirożyński, Wypowiedź w dyskusji o aktualnych problemach komisji finansów, budżetu i planu, „Gospodarka i Administracja Terenowa” 1963, nr 5, s. 4.

13 M. Weralski, Budżet czy plan finansowy?, „Państwo i Prawo” 1965, nr 2, s. 212 (pojęcie deficytu planu kredytowego nawiązuje do stosowanych wówczas terminów limitów kredytowych oznaczających współcześnie limity wydatków budżetowych).

14 Z. Rajewski, Powiq̨zanie NPG z systemem finansowym państwa, Gospodarka Planowa 1958, „Państwo i Prawo” 1965, nr 2, s. 34-39.

15 Tamże, s. 34-39.

16 T. Grodyński, Zasady gospodarowania budżetowego w Polsce na tle porównawczym, Kraków 1932, s. 388 i n.

17 J. Kaleta, Gospodarka..., s. 259. 
Niemniej powszechnie przyjmowano zasadę, że planowanie budżetowe nie może się ograniczać do planowania rocznego czy kwartalnego. Takie ograniczenie prowadziłoby bowiem do nieracjonalnego działania i nie stwarzałoby odpowiednich warunków do prowadzenia właściwej polityki budżetowej, która aby była skuteczna, musiała być realizowana w warunkach względnej stabilizacji. Cecha „długodystansowości” planu określana była jako jedna z niezbędnych warunków „dobrego planu”, który jest odzwierciedleniem zasady, że „warto sięgać planem jak najdalej w przyszłość, gdyż rozumny wybór działań wcześniejszych zależy od tego, co stanie się później”18.

\section{Początki wieloletniego planowania budżetowego}

Konieczność opracowywania wieloletnich planów budżetowych odnosiła się głównie do budżetów terenowych ${ }^{19}$. Pierwszą próbą wprowadzenia w Polsce wieloletniego planowania budżetowego na poziomie lokalnym było opracowanie jednostkowych bilansów dochodów i wydatków budżetowych na lata 1961-1965 w zakresie budżetów terenowych. Wydziały finansowe ówczesnych prezydiów wojewódzkich i powiatowych rad narodowych opracowały na polecenie ministra finansów bilanse dochodów i wydatków budżetowych na okres pięciu lat w pełnej klasyfikacji budżetowej do paragrafu włącznie. Ponadto opracowały one szereg załączników do tych bilansów, między innymi zbiorcze zestawienie akumulacji finansowej przedsiębiorstw i jej podziału oraz zbiorcze zestawienia finansowania inwestycji i remontów kapitalnych ${ }^{20}$. Bilanse te stanowiły jedynie orientacyjną kalkulację zapotrzebowania finansowego i jego pokrycia, a tym samym nie mogły stanowić bezpośredniej podstawy dokonywania

18 T. Kotarbiński, Traktat o dobrej robocie, Wrocław 1975, s. 183.

19 C. Bielecki, B. Winiarski, Gospodarka rad narodowych, Warszawa 1960, s. 112; M. Jaroszyński, Zagadnienia rad narodowych, Warszawa 1961, s. 82 i n.; J. Kaleta, Terenowe planowanie budżetowe w Polsce Ludowej, Warszawa 1968, s. 63 i n.; J. Lubowicki, Budżet i zasady budżetowe, „Państwo i Prawo” 1964, nr 8-9, s. 212; M. Weralski, Rola budżetu w planowaniu gospodarczym, Warszawa 1963, s. 215-218.

20 J. Kaleta, Gospodarka..., s. 261. 
wydatków budżetowych ${ }^{21}$. Należy zaznaczyć, że podstawą dla opracowania bilansów były projekty terenowych Planów Rozwoju Gospodarki Narodowej na lata 1961-1965 oraz obowiązujące w 1959 r. stawki płac, ceny, taryfy, systemy finansowe przedsiębiorstw terenowych, podział zysku w przedsiębiorstwach handlowych oraz systemy i źródła finansowania inwestycji i kapitalnych remontów ${ }^{22}$.

Jak podkreślano w literaturze przedmiotu, największym mankamentem tak rozumianego planowania wieloletniego było to, że wydziały finansowe, nie rozporządzając w momencie opracowywania bilansów niezbędnymi danymi w postaci pięcioletnich normatywów środków wyrównawczych, pięcioletnich planów finansowych przedsiębiorstw, zmuszone były do dokonywania orientacyjnych szacunków. Szacunki, te, zwłaszcza w bilansach powiatowych, z uwagi na fakt, że planowane kwoty wydatków znacznie przekraczały możliwości finansowania planowanych zadań, były nierealne. Ponadto wadą tych bilansów był brak ich skoordynowania z pięcioletnimi planami gospodarczymi rad narodowych ${ }^{23}$.

Dalsza próba wieloletniego planowania budżetowego w Polsce była zapoczątkowana wprowadzeniem, począwszy od 1965 r., dwuletniego planowania niektórych dochodów i wydatków budżetowych. Należy zaznaczyć, że wytyczne władz centralnych do opracowania budżetów terenowych na rok 1965 oraz niektórych dochodów i wydatków budżetu na rok 1966 zobowiązały prezydia wojewódzkich rad narodowych do opracowania i przedłożenia tym władzom jednocześnie z projektem zbiorczego budżetu województwa, m.in. planu niektórych dochodów i wydatków budżetu na rok 1966. W szczególności wprowadzono równolegle obowiązek planowania na rok 1966 obok kalkulacji dochodów i wydatków budżetu na 1966 r. ${ }^{24}$ Niemniej i ta próba planowania wieloletniego okazała się nieskuteczna, bowiem jak podkreślano, planowaniem tym nie objęto podstawowej grupy dochodów budżetowych, tj. dochodów od przedsię-

21 Z. Pirożyński, Zadania i metody pięcioletniego planowania finansowego w gospodarce rad narodowych, „Finanse” 1959, nr 11, s. 4.

22 A. Grim, Wieloletnie planowanie budżetowe w systemie rad narodowych, Finanse, Warszawa 1971, s. 3.

23 J. Kaleta, Gospodarka..., s. 262.

24 A. Grim, Wieloletnie planowanie...., s. 7. 
biorstw uspołecznionych oraz wydatków na inwestycje i „remonty kapitalne” środków trwałych, a w ten sposób nie zagwarantowano realności pięcioletnich planów gospodarczych.

Pomimo niepowodzeń planowania wieloletniego w dalszym ciągu idea planowania wieloletniego była pożądana, o czym świadczy m.in uchwała VI Zjazdu Polskiej Zjednoczonej Partii Robotniczej z 1971 r., która zobowiązywała do przechodzenia na wieloletnie planowanie budżetowe i pięcioletnie bilansowanie dochodów i wydatków rad narodowych ${ }^{25}$. Wytyczone w uchwale PZPR założenia reformy budżetowej wprowadzono eksperymentalnie w kilku ówczesnych województwach (poznańskim, szczecińskim i wrocławskim oraz w miastach Poznaniu i Wrocławiu). Sam eksperyment polegał na wprowadzeniu dwuletniego planowania budżetowego na lata 1974-1975 i znacznym zwiększeniu dochodów własnych rad narodowych w dochodach ogółem przez wprowadzenie kilku nowych źródeł dochodów własnych. Według założeń eksperymentu budżety terenowe wszystkich stopni miały być oparte przede wszystkim na własnych dochodach rad narodowych. Dochody te miały pokrywać w pełni bieżące wydatki budżetowe, zaś dotacje celowe z budżetu centralnego były przeznaczone głównie na finansowanie nakładów inwestycyjnych. W budżetach objętych eksperymentem zrezygnowano z udziałów w dochodach budżetu centralnego i dotacji wyrównawczej jako instrumentu równoważenia dochodów i wydatków. Wyniki eksperymentu wykazały, że oparcie budżetów terenowych głównie na dochodach własnych spowodowało, ze efekty gospodarki budżetowej były zależne przede wszystkim od wyników pracy rad narodowych i podległych im organów administracji, a nie od organów centralnych.

Niemniej pomimo takich rezultatów nie wprowadzono w latach 70 . powszechnego planowania budżetowego i pięcioletniego bilansowania dochodów i wydatków rad narodowych, choć zalety planowania wieloletniego w dalszym ciągu były dostrzegane. Wiążąca bowiem była zasada, że planowanie roczne w sposób sztuczny „przerywa” ciągłość różnorod-

25 Uchwała VI Zjazdu Partii z 1971 r. [w:] Polska Zjednoczona Partia Robotnicza, VI Zjazd Polskiej Zjednoczonej Partii Robotniczej 6-11.XII.1971 r., Warszawa 1972, s. 16. 
nych zjawisk gospodarczych i społecznych, a ciągłość tę lepiej oddają plany wieloletnie, które jednocześnie chroniłyby przed konstruowaniem wieloletnich planów gospodarczych o niezrównoważonej strukturze, zabezpieczając proporcjonalny i ciągły rozwój gospodarki ${ }^{26}$. Ponadto podkreślano, że planowanie wieloletnie przy odpowiednio ograniczonej szczegółowości stwarzało usystematyzowanie podstawy do podejmowania w ramach polityki budżetowej decyzji, których długookresowe konsekwencje, wybiegające poza rok budżetowy, mogłyby być już z góry, przed podjęciem tych decyzji rozpoznane i przeanalizowane w stopniu, na jaki pozwala aktualny w tej chwili stan wiedzy ${ }^{27}$.

Dlatego też postulat planowania wieloletniego został uwzględniony w nowej (uchwalonej w 1983 r.) ustawie o systemie rad narodowych i samorządzie terytorialnym ${ }^{28}$, która wskazywała, że podstawą kompleksowego planowania terytorialnego jest pięcioletni plan społeczno-gospodarczy powiązany $\mathrm{z}$ pięcioletnim planem finansowania zadań uwzględniający ogólne kierunki rozwoju, wyznaczone w planach perspektywicznych. W takim ujęciu plan roczny miał mieć charakter wykonawczy w stosunku do planu pięcioletniego. Należy podkreślić, że podstawą tak rozumianego planowania wieloletniego były przygotowywane wielowariantowe założenia oraz projekty planów, które sporządzane były przez terenowe organy administracji państwowej zgodnie z wytycznymi rady narodowej $^{29}$. Niemniej pomimo obowiązywania przedmiotowej regulacji już od 17 czerwca 1984 r. ostatecznie pięcioletnie plany finansowania zadań oraz ustalenie pięcioletnich udziałów w dochodach budżetu centralnego rady narodowe uchwalały, poczynając od uchwalenia takich planów na lata $1986-1990^{30}$. Wówczas też system planowania wieloletniego doty-

26 E. Ruśkowski, Planowanie i programowanie finansowe [w:] C. Kosikowski, E. Ruśkowski (red.), Finanse i prawo finansowe, Łódź 1994, s. 35.

27 R. Skarżyński, Nauka finansów i polityka finansowa w Polsce Ludowej (konferencja jubileuszowa), Warszawa, 2-4 czerwca 1980 r. Cz. 2, Szkoła Główna Planowania i Statystyki, Warszawa 1980, s. 136.

28 Ustawa z dnia 20 lipca 1983 r. o systemie rad narodowych i samorządu terytorialnego, Dz.U. Nr 41, poz. 185.

29 Zob. art. 39-41 ustawy z dnia 20 lipca 1983 r. o systemie rad narodowych i samorządu terytorialnego, Dz.U. Nr 41, poz. 185, dalej: u.s.r.n.s.t.

30 Zob. art. 181 u.s.r.n.s.t. 
czył bilansu szacunkowego dochodów budżetowych oraz bilansu finansowego państwa - na szczeblu centralnym i planów finansowych zadań na szczeblu wojewódzkim i podstawowym ${ }^{31}$. Warto zaznaczyć, że gospodarkę finansową prowadzono wtedy w oparciu o zrównoważony budżet lub budżet z planową nadwyżką. Jednakże była to równowaga osiągana w sposób sztuczny, bowiem socjalizm aż do roku 1989 „nie znał” (lub raczej wykluczał z nomenklatury) pojęcia deficytu i długów publicznych.

Bezpośrednim skutkiem tak rozumianej polityki wieloletniego planowania finansowego było wprowadzenie systemu finansowego określanego mianem centralizacji finansowej, który realizowany był za pomocą budżetu państwa, gdzie budżet centralny obejmował budżety rad narodowych. Warto zaznaczyć, że pomimo określenia znaczenia wieloletniego planowania budżetowego nie zrezygnowano z tworzenia budżetów rocznych, których konieczność utrzymywania wynikała z konieczności konkretyzowania i rozwijania zadań zawartych w budżetach wieloletnich, a ponadto stanowiły one ważne narzędzie kontroli organów administracji państwowej przez organy władzy państwowej ${ }^{32}$.

Konsekwencją zastosowania sytemu finansowego opartego na centralizacji finansowej był także „odgórny” tryb ustalania budżetów. Zgodnie z nim rady narodowe, uchwalając budżety terenowe, miały kierować się ustaleniami zawartymi w ustawie budżetowej oraz uchwałach budżetowych rad narodowych wyższego stopnia.

Wśród zwolenników „odgórnego” trybu ustalania budżetów terenowych dominowały argumenty wskazujące, że w ówczesnych warunkach możliwy jest tylko taki sposób uchwalenia budżetów, ponieważ realne wytyczne do opracowania budżetów terenowych mogą być sporządzone dopiero w listopadzie, a co za tym idzie, „oddolny” tryb uchwalania budżetów musiałby doprowadzić do przesunięcia terminu uchwalania budżetu państwa w najlepszym razie do stycznia ${ }^{33}$. Przeciwnicy takiego podejścia wskazywali natomiast, że „oddolny” tryb uchwalania budżetów za-

\footnotetext{
Zob. art. 26 Prawa budżetowego z 1984 r.

J. Kaleta, Gospodarka..., s. 266.

A.W. Zawadzki, Uprawnienia budżetowe rad narodowych, „Prace Zakładu Budżetu Państwa” 1963, nr 7, s. 15.
} 
pewnia szerszy udział społeczeństwa w planowaniu budżetowym i pobudza inicjatywę społeczną do pełniejszego wykorzystania rezerw lokalnych i podniesienia stopnia zaspokojenia potrzeb ludności ${ }^{34}$. Ponadto wskazywano, że „oddolny” tryb przygotowywania budżetów umożliwia decentralizację, która z kolei stwarzała radom narodowym pole do aktywności społecznej i pobudzała ich własną inicjatywę ${ }^{35}$.

Na uwagę zasługują także poglądy, zgodnie z którymi przyjęcie „oddolnego” czy „odgórnego” trybu uchwalania budżetów terenowych nie miało praktycznie większego znaczenia, bowiem różnice pomiędzy tymi dwoma trybami nie miały związku z centralizacją czy (de)centralizacją finansów publicznych. Zgodnie bowiem z zasadą: zniesienie wszystkich wskaźników dyrektywnych przy zastosowaniu trybu „odgórnego”, a jednocześnie przyjęcie trybu „oddolnego”, nie wyklucza wprowadzenia dużej liczby tych wskaźników ${ }^{36}$. Niemniej stanowisko takie zostało zanegowane w ten sposób, że „odgórny” tryb uchwalania budżetu będzie miał sens tylko wówczas, gdy ustalenia zawarte w budżecie wyższego szczebla będą wiążące dla rad narodowych niższych stopni ${ }^{37}$. Ponadto dość szybko okazało się, że planowanie wieloletnie zostało sprowadzone do wykonania założonych zadań rzeczowych, marginalizując osiągnięcie zysku i większych dochodów budżetowych. Dlatego też zaledwie niespełna po pięciu latach obowiązywania przepisy dotyczące obowiązkowego planowania wieloletniego zostały uchylone ${ }^{38}$.

Powody, które ostatecznie przyczyniły się do negatywnej oceny planowania budżetowego, dotyczyły przede wszystkim nadmiernego wykorzystywania statystycznej metody planowania oraz ekstrapolacji przeszłości na przyszłość. Ponadto do największych mankamentów planowania

34 M. Weralski, Ogólne zasady gospodarki finansowej rad narodowych, „Ruch Prawniczy, Ekonomiczny i Socjologiczny” 1965, nr 3, s. 156.

35 L. Kurowski, Les finances dans les ètats socialistes, Paryż 1962, s. 61, cyt. za: J. Kaleta, Gospodarka..., s. 274.

36 J. Harasimowicz, Zagadnienia uchwalania budżetów zbiorczych w socjalizmie, Studia Podatkowe i Budżetowe, Toruń 1964, s. 257-258.

37 J. Kaleta, Gospodarka..., s. 275.

38 Zob. art. 2 ust. 1 pkt 3 ustawy z dnia 10 maja 1990 r. - Przepisy wprowadzające ustawę o samorządzie terytorialnym i ustawę o pracownikach samorządowych, Dz.U. $\mathrm{Nr}$ 32, poz. 191. 
budżetowego tego okresu zaliczano nadmierne scentralizowanie systemu budżetowego. Prezydia rad narodowych, mając możliwość skorzystania z rezerw budżetowych organów wyższego stopnia (np. gromadzkie prezydia rad narodowych występowały z wnioskiem o dotacje do powiatowych prezydiów rad narodowych), celowo nie ujawniały rzeczywiście posiadanych przez siebie środków, aby przez to uzyskać większe szanse na otrzymanie dodatkowych dotacji budżetowych od tych prezydiów, które oszczędnie gospodarowały środkami publicznymi ${ }^{39}$. Działania takie spowodowały jednocześnie liczne zmiany wysokości dotacji, których częstotliwość była tak duża, że skutecznie paraliżowało to planowanie wielolet$n^{40}{ }^{40}$. Przyczyną krytycznej oceny planowania wieloletniego było także nieprzyjęcie realnych parametrów finansowych w postaci cen, opłat, stóp procentowych, kursów walutowych, właściwej wyceny majątku jednostek finansowanych, które mogłyby służyć za obiektywne podstawy planowania wieloletniego. Niewątpliwą wadą planowania wieloletniego było również niewystarczające zaangażowanie organów przedstawicielskich (Sejmu i rad narodowych) w proces przygotowywania i uchwalania budżetów, których rola ograniczała się zwykle do mechanicznego uchwalania nierealnych, rządowych projektów budżetowych i tolerowania przekroczeń deficytu budżetowego, nawet o 300\% w 1989 r. ${ }^{41}$ Do nieprawidłowości planowania wieloletniego należy zaliczyć także przewlekłe, pracochłonne i zbyt szczegółowe procedury przygotowywania budżetów w ujęciu wieloletnim. Słabym punktem planowania wieloletniego okazało się również zbyt późne uchwalanie budżetu państwa oraz budżetów terenowych (po-

39 J. Kaleta, Konieczne zmiany w systemie równoważenia budżetów terenowych, „Finanse” 1971, nr 7, s. 20.

40 Przeprowadzone badania na przykładzie dawnego województwa wrocławskiego wykazały, że dotacja budżetowa Wojewódzkiej Rady Narodowej została w 1966 r. zmieniona 76 razy; w 1967 r. - 81 razy; w 1968 r. - 82 razy; w 1969 r. - 64 razy; w 1970 r. 33 razy. Konsekwencją takich działań była konieczność wprowadzenia zmian dotacji w budżetach powiatowych w liczbie 1832 razy w 1966 r.; 1549 razy - w 1967 r.; w 1968 r. - 1317 razy; w 1969 r. - 1269 razy i w 1970 r. - 1150 razy, cyt. za: J. Kaleta, Konieczne zmiany w systemie równoważenia..., s. 20-23.

41 J. Kaleta, Planowanie budżetowe [w:] J. Kaleta (red.), Reforma systemu finansowego państwa, Warszawa 1991, s. 87. 
wodujące z reguły wyłączenie pierwszego kwartału z budżetu) ${ }^{42}$ oraz niestabilność założeń polityki społecznej i gospodarczej, prymitywizm metod i technik planowania finansowego ${ }^{43}$.

\section{Propozycje zmian koncepcji planowania budżetowego wynikające z doświadczeń jego stosowania w Polskiej Rzeczpospo- litej Ludowej}

Reasumując, zgodzić należy się z stanowiskiem, że planowanie budżetowe funkcjonujące w okresie Polskiej Rzeczpospolitej Ludowej nie odgrywało większej roli w racjonalizacji procesów związanych z gromadzeniem i wydatkowaniem środków publicznych i miało charakter pomocniczy względem planowania rzeczowego ${ }^{44}$.

Mimo że do końca lat 80. nie wypracowano w Polsce racjonalnego i skutecznego systemu planowania wieloletniego, w literaturze przedmiotu z początku lat $90 \mathrm{XX}$ w. wskazywano na możliwe zmiany, których implementacja umożliwiłaby, zdaniem ich autorów, na udoskonalenie metody planowania wieloletniego w nowej perspektywie społeczno-politycznej okresu potransformacyjnego.

Do najważniejszych propozycji przebudowy planowania wieloletniego na szczeblu centralnym zaliczono konieczność zapewnienia pełnej zgodności planowania budżetowego i rzeczowego oraz ściślejszego powiązania budżetów z innymi planami państwa. Nie bez znaczenia była także potrzeba zaniechania dokonywania corocznych zmian przepisów budżetowych, a zwłaszcza obowiązującej wówczas ustawy o prawie budżetowym. Ponadto postulowano, aby planowanie budżetowe było poddane procesowi zdecentralizowania i aby w ten sposób skutecznie przysłużyć się zwiększeniu udziału społeczeństwa w planowaniu budżetowym. Ważnym czynnikiem wpływającym na unowocześnienie planowania wie-

\footnotetext{
J. Kaleta, Planowanie..., s. 81-82.

E. Ruśkowski, Planowanie i programowanie finansowe..., s. 36.

J. Kaleta, Planowanie..., s. 81-82.
} 
loletniego miałoby być także odejście od stosowania metod uznaniowych i statystycznych oraz przejście na planowanie wieloletnie, wykorzystujące obiektywne kryteria budżetowe, wykorzystywane w gospodarce wolnorynkowej. Jak podkreślano, elastyczne kształtowanie parametrów finansowych i posiadanie właściwych prognoz koniunktury gospodarczej nie tylko są koniecznymi warunkami realnego planowania zarówno dochodów, jak i wydatków budżetowych, ale także stanowią niezbędny warunek planowania budżetowego.

Pożądaną zmianą było również zerwanie z podporządkowywaniem sobie przez organy centralne beneficjentów funduszy rezerwowych tworzonych na szczeblu centralnym i wojewódzkim. Uzależnienie się bowiem budżetów terenowych od transferów środków z rezerw budżetowych nie sprzyjało racjonalnemu planowaniu budżetowemu, lecz wyzwalało nieuzasadniony brak troski o środki publiczne. W tym zakresie zwrócono uwagę na konieczność ustabilizowania dochodów wyrównawczych dla wszystkich rad narodowych na okresy pięcioletnie oraz ewentualne ich automatyczne korygowanie za pomocą stopy inflacji (deflacji).

Warunkiem niezbędnym, a odnoszącym się do usprawnienia metody planowania wieloletniego na szczeblu centralnym, było także stworzenie warunków prawnych umożliwiających egzekwowanie dyscypliny budżetowej. Tylko dzięki odpowiedzialności za przekroczenia ustalanych wydatków budżetowych oraz niepełną realizację dochodów budżetowych możliwym jest racjonalizacja planowania budżetowego. Postulowaną zmianą było także uchwalenie budżetu państwa na co najmniej trzy miesiące przed rozpoczęciem roku budżetowego, a przez to urealnienie zasady, że plan zawsze powinien dotyczyć przyszłości, a nigdy przeszłości. W zaproponowanych zmianach nie zabrakło też wniosku o uproszczenie procedury planowania budżetowego oraz ograniczenia szczegółowości uchwalanych budżetów.

Natomiast w zakresie planowania wieloletniego na poziomie budżetów lokalnych oprócz propozycji podnoszonych w aspekcie budżetu centralnego, a mających równocześnie zastosowanie do budżetów terenowych (np. odejścia od metod statystycznych i ekstrapolacji, oparcie procesów budżetowych na decentralizacji, zaprzestania z nadmiernego korzy- 
stania z rezerw budżetowych organów wyższego stopnia czy uchwalania budżetów na trzy miesiące przed rozpoczęciem roku budżetowego) do pożądanych zmian zaliczono, m.in. wprowadzenie wielowariantowego opracowywania projektów budżetów i prezentowania różnych wariantów właściwym organom przedstawicielskim; zwiększenie udziału w dochodach własnych rad narodowych w ogólnych kwotach dochodów budżetowych; rozszerzenie uprawnień w procesie planowania budżetowego dla kierowników jednostek i zakładów budżetowych; szersze zainteresowania społeczeństwa problematyką budżetową poprzez poddawanie budżetów kontroli społecznej za pomocą możliwości publikowania na łamach prasy podstawowych założeń budżetowych ${ }^{45}$.

Ponadto do postulatów doskonalenia procesów planowania budżetowego zaliczano konieczność wyeliminowania konstruowania budżetu lokalnego „od góry”. W takim układzie bowiem zadania finansowane z budżetu są traktowane jako narzucone, co nie skłania wykonawców zadań do racjonalnego wykorzystywania środków i lepszej realizacji wiązki celów jednostki samorządowej. Dlatego też zaangażowanie w procesy związane z przygotowaniem budżetu pracowników niższego szczebla, pomimo że było bardziej skomplikowane, żmudne i wymagające więcej czasu, dawało większe gwarancje, że planowanie i wykonanie budżetu będzie procesem świadomym ${ }^{46}$. W tym zakresie zgodzić należy się z poglądem, zgodnie z którym zastosowanie nowatorskich metod planowania budżetowego (np. programowanie budżetowe, budżet zadaniowy) możliwe jest wyłącznie przy wykorzystaniu metody tworzenia budżetu „od dołu”, budżetu demokratycznego, budżetu oderwanego od historycznych kosztów (wydatków). Jak podkreślała to literatura przedmiotu, trudno dokonywać cięć w wydatkach na dane dziedziny z jednoczesnym powiększaniem wydatków na inne dziedziny bez negatywnych czy wręcz wrogich postaw osób odpowiedzialnych za realizację lokalnego budżetu. Tylko w sytuacji, gdy osoby te będą „wciągnięte” w proces budżetowy, a podjęte rozwiązania kompromisowe $\mathrm{w}$ tym znaczeniu, że np. $\mathrm{w}$ danym roku są przyjmowane dane priorytety, a w następnych latach inne, istnieją

\footnotetext{
Tamże, s. 81-82.

46 S. Owsiak, Budżet władz lokalnych, Warszawa 2009, s. 33.
} 
duże szanse skutecznego posługiwania się budżetem jako narzędziem racjonalizacji wydatków publicznych na poziomie mikroekonomicznym ${ }^{47}$.

\section{Wnioski końcowe}

Zalety wieloletniego planowania finansowego dostrzegane były w Polsce już od lat $60 \mathrm{XX}$ w. Mimo że pierwsza próba wieloletniego planowania finansowego, odnosząca się do budżetów lokalnych, miała miejsce dopiero w latach 1961-1965, to już wówczas charakterystyczne było to, że prognozowane kwoty dochodów oraz limity wydatków były nierealne i nieskoordynowane z budżetem państwa. Ponadto wraz z rozwojem myśli dotyczącej wieloletniego planowania finansowego coraz wyraźniej zarysowywała się potrzeba oparcia budżetów terenowych o własne dochody. Należy zaznaczyć, że już w tym okresie pojawiły się także próby odpowiedzi na pierwsze fundamentalne pytania dotyczące wyboru koncepcji wieloletniego planowania finansowego. W tym zakresie na szczególną uwagę zasługuje dyskusja pomiędzy zwolennikami centralistycznego („odgórnego”) sposobu wieloletniego planowania finansowego oraz lokalnego („oddolnego”) wieloletniego planowania finansowego. Pomimo ówczesnej sytuacji politycznej dostrzeżono, że koncepcja wieloletniego planowania finansowego, przygotowywanego „od dołu”, w budżetach terenowych jest bardziej efektywna niż metoda rządowego wieloletniego planowania finansowego realizowanego z wyłączeniem tzw. czynnika obywatelskiego. Zaakcentowania wymaga także fakt, że przed rokiem 1989 koncepcje wieloletniego planowania finansowego w Polsce dotyczyły bardziej budżetu państwa niż budżetów terenowych.

Reasumując, należy stwierdzić, że podejmowane w okresie Polskiej Rzeczypospolitej Ludowej próby planowania finansowego w wymiarze wieloletnim, które ze względu na poszukiwanie optymalnego sposobu planowania finansowego określić można mianem eksperymentów, nie były czasem straconym dla zrozumienia koncepcji wieloletniego pla-

47 J.D. Suver, B.R. Neumann, Management Accounting for Healthcare Organizations, Chicago 1990, s. 149 i n.; W.O. Cleverely, Essentials of Health Care Finance, Gaithersburg 1992, s. 275-314, s. 477-478, cyt. za: S. Owsiak, Budżet..., s. 34. 
nowania finansowego. Z doświadczeń tych wynika bowiem fakt, że wieloletnie planowanie finansowe musi opierać się przede wszystkim na rzetelnych i realistycznych danych dotyczących podstawowych parametrów budżetowych. Konsekwentne nieprzestrzeganie tej podstawowej zasady w ostatecznym rozrachunku musi skutkować zachwianiem systemu finansów publicznych nawet, jeżeli proces ten zostałby oparty o najbardziej skrupulatne mechanizmy wieloletniego planowania finansowego. Pomimo podejmowania w tym okresie tak wielu skomplikowanych i czasochłonnych procesów, składających się na zasady wieloletniego planowania finansowego, proces ten nie może ograniczać się jedynie do udowodnienia za wszelką cenę zrównoważenia bilansu dochodów i wydatków budżetu państwa oraz struktur terenowych. Stoję również na stanowisku, że dzięki doświadczeniom wynikającym z podejmowanych działań w okresie PRL na rzecz wieloletniego planowania finansowego ewentualne dalsze próby zmierzające do powtórnego zastosowania w porządku prawnym koncepcji wieloletniego planowania finansowego, opartego na „odgórnym” planowaniu finansowym, nacechowanym centralizmem decyzyjnym oraz ograniczeniem udziału społeczeństwa w procesie konstruowania budżetu zwłaszcza na poziomie lokalnym będą zabiegami sprzecznymi z ideą racjonalizacji sposobu zarządzania finansami publicznymi. Niezależnie jednak od powyższych wniosków za słuszną uważam dalszą potrzebę oceny: czy obecne rozwiązania prawne dotyczące koncepcji wieloletniego planowania finansowego, zwłaszcza na poziomie samorządu terytorialnego, czerpią z opisanych wyżej doświadczeń okresu PRL, czy też w dalszym ciągu dochodzi w tym zakresie do powielania już wcześniej zdiagnozowanych błędów dotyczących wieloletniego planowania finansowego. Stanowisko takie jest tym bardziej uzasadnione, że w obecnym stanie prawnym sztandarowy instrument planowania wieloletniego na poziomie samorządu terytorialnego (wieloletnia prognoza finansowa) zgodnie z normą ustawową powinien być oparty o regułę realistyczności prognozowanych danych. 


\section{Bibliografia:}

Bielecki C., Winiarski B., Gospodarka rad narodowych, Polskie Wydawnictwa Gospodarcze, Warszawa 1960.

Bolland S., Ekonomiczne i ustrojowe aspekty reformy prawa budżetowego, „Ruch Prawniczy i Ekonomiczny” 1963, nr 3, s. 77-95.

Branik J., K otazce souladu hmotnych a financnych zdrojom, „Finance a Uver” 1963, nr 4, s. 255-310.

Cleverely W. O., Essentials of Health Care Finance, Apsen Publishers, Inc., Gaithersburg, Maryland 1992.

Federowicz Z., Zagadnienie reformy polskiego systemu podatkowego, „Ruch Prawniczy i Ekonomiczny” 1963, nr 3, s. 6-15.

Grodyński T., Zasady gospodarowania budżetowego w Polsce na tle porównawczym, Polska Akademia Umiejętności, Kraków 1932.

Grim A., Wieloletnie planowanie budżetowe w systemie rad narodowych, „Finanse” 1971, nr 8, s. 1-10.

Harasimowicz J., Zagadnienia uchwalania budżetów zbiorczych w socjalizmie, Studia Podatkowe i Budżetowe, Toruń 1964, s. 257-258.

Jaroszyński M., Zagadnienia rad narodowych, Państwowe Wydawnictwo Naukowe, Warszawa 1961.

Kaleta J., Konieczne zmiany w systemie równoważenia budżetów terenowych, „Finanse” 1971, nr 7, s. 11-24.

Kaleta J., Planowanie budżetowe [w:] J. Kaleta (red.), Reforma systemu finansowego państwa, Państwowe Wydawnictwo Ekonomiczne, Warszawa 1991.

Kaleta J., Terenowe planowanie budżetowe w Polsce Ludowej, Państwowe Wydawnictwo Ekonomiczne, Warszawa 1968.

Kaleta J., Gospodarka budżetowa, Państwowe Wydawnictwo Ekonomiczne, Warszawa 1985.

Kosikowski C., Naprawa finansów publicznych w Polsce (Przyczyny, Metodologia, Kierunki i Propozycje), Temida 2, Białystok 2011.

Kotarbiński T., Traktat o dobrej robocie, Zakład Narodowy im. Ossolińskich, Wrocław 1975.

Kurowski L., Les finances dans les ètats socialistes, Librairie générale de droit et de jurisprudence, Paryż 1962.

Kurowski L., Planowanie budżetowe $w$ ramach socjalistycznego planowania gospodarczego „Państwo i Prawo” 1961, nr 8-9, s. 273.

Lange O., Optymalne decyzje. Zasady gospodarowania, PWN, Warszawa 1964. 
Lubowicki J., Budżet i zasady budżetowe, „Państwo i Prawo” 1964, nr 8-9, s. 206-217.

Margolin N. S., Płanirowanije finansow, Moskwa 1960.

Owsiak S., Budżet władz lokalnych, Polskie Wydawnictwo Ekonomiczne, Warszawa 2009.

Pirożyński Z., Wypowiedź w dyskusji o aktualnych problemach komisji finansów, budżetu i planu, „Gospodarka i Administracja Terenowa” 1963, nr 5, s. 4.

Pirożyński Z., Zadania i metody pięcioletniego planowania finansowego $w$ gospodarce rad narodowych, „Finanse” 1959, nr 11, s. 1-6.

Rajewski Z., Powiqzzanie NPG z systemem finansowym państwa, Gospodarka Planowa 1958, „Państwo i Prawo” 1965, nr 2, s. 34-39.

Ruśkowski E, Planowanie i programowanie finansowe [w:] C. Kosikowski, E. Ruśkowski (red.), Finanse i prawo finansowe, KiK, Łódź 1994.

Skarżyński R., Nauka finansów i polityka finansowa w Polsce Ludowej (konferencja jubileuszowa), Warszawa 2-4 czerwca 1980 r. Cz. 2. Szkoła Główna Planowania i Statystyki, Warszawa 1980.

Suver J. D., Neumann B. R., Management Accounting for Healthcare Organizations, Pluribus Press, Inc., Division of Teach'em, Inc., Chicago 1990.

Swianiewicz P., Finanse lokalne - teoria i praktyka, Municipium, Warszawa 2004.

Weralski M., Budżet czy plan finansowy ?, „Państwo i Prawo” 1965, nr 2, s. $208-217$.

Weralski M., Ogólne zasady gospodarki finansowej rad narodowych, „Ruch Prawniczy, Ekonomiczny i Socjologiczny” 1965, nr 3, s. 143-156.

Weralski M., Rola budżetu w planowaniu gospodarczym, Państwowe Wydawnictwo Ekonomiczne, Warszawa 1963.

Weralski M., Zwiq̨zki budżetu PRL z narodowym planem gospodarczym i innymi planami finansowymi [w:] W. Brzeziński, J. Kaleta, L. Martan, A. Wolter, M. Weralski (red.), Problemy prawne planowania gospodarczego, Państwowe Wydawnictwo Naukowe, Warszawa 1964.

Zawadzki A. W., Uprawnienia budżetowe rad narodowych, „Prace Zakładu Budżetu Państwa” 1963, nr 7, s. 10-20. 